\title{
An Ex-Post Cost - Benefit Analysis of Bolu Mountain Tunnel Project ${ }^{1}$
}

\author{
Gaye KOCABAŞ', Barış Serkan KOPURLU²
}

\begin{abstract}
This paper analyzes the feasibility of Bolu Mountain Tunnel which is one of the most costly highway projects in Turkey. The project continued for about seventeen years and opened to use in 2007. Internal Rate of Return concept is used as a decision rule to asses the net benefit stream of the project. As the tunnel construction had not finished at the deadline planned by the earliest project appraisal, the necessity of tunnel construction became controversial among the society as it requires high investment costs which are withdrawn from other resources of the economy. The analysis is conducted for a 50 year period. According to the results, Bolu Mountain Tunnel project is not economically feasible since the Net Present Value of the project is highly negative at $\% 12$ discount rate level. The NPV and IRR figures are recalculated under different scenarios but even in the best case the figures are negative.
\end{abstract}

Key Words: Cost - benefit analysis, internal rate of return, discount rate, net present value, Bolu Mountain Tunnel, transportation projects.

\section{INTRODUCTION}

Cost - benefit analysis (CBA) is the most widely used project evaluation method by both public and private sectors for comparison of various projects according to their costs and benefits. The present values of a project's costs are calculated and benefits are estimated for comparison. If the comparison will be among several projects, the most beneficial project is chosen. If the decision will be made for one project, the project is concluded worthwhile if the net benefits exceed the net costs. (Unsal, 2004)

Although CBA has its roots back to 19th century when it had firstly introduced by a French engineer Arsene-JulesEtienne-Juvenal Dupuit in 1844, it did not commonly used until 20th century. CBA is redefined in mid-1950's corresponding to economic standards. In 1950's and 60's, the modern welfare economists are supported by USA and other governments to set the formal principles of CBA. The popularity of CBA in 1960's had declined in 1970's because the theorists and agencies using CBA began to question the method. After that period, there has been a rapid increase both in literature and practical use of CBA. Today, CBA is widely used and required by EU and other countries as well as USA.

The purpose of using CBA is different for public and private sectors. While the private sector uses the method only for profit maximization, the public sector uses it to maximize social benefit. The aim of public sector for using CBA can also be stated as to allocate resources efficiently among the projects to raise the social welfare. As the purpose is stated as to maximize social welfare, the standard of CBA is the Potential Pareto Condition or in other words Kaldor-Hicks Rule which has its roots from Pareto Optimality theorem of welfare economics (Nas, 1996).

\subsection{Literature Review}

Cost benefit analysis is the most widely used appraisal technique by public authorities. The method is especially used for the evaluation of infrastructure and transport projects. The main rationale for the usage of CBA is the opportunity of ranking numerous projects that will be selected to be undertaken. As the CBA is conducted for almost every infrastructure project, especially for transport projects, some specific examples of transport project evaluation will be given throughout the section. Although the literature is very wide we have considered a few of them, as the purpose is giving a broad idea of how CBA is used and how the measures can vary.

Despite some of its weaknesses, the advantage of CBA is its ability of monetizing all impacts. (Although some effects cannot be monetized, CBA also mentions about their significance.) As a result, projects can be ranked on a standard measure.

\footnotetext{
${ }^{1}$ Assistant Audit Specialist Anadolu Group, Turkey, gaye.kocabas@anadolugrubu.com.tr 
The use of CBA as an appraisal technique for transport projects had been risen in late 1960's and early 1970's. Although practical use of CBA has its roots from USA, it is also required by EU for the funding of the projects. In the enlargement process, new regulations are made by EU commission in the light of regional policy objectives to provide efficiency for the development. The objective of regional policy of EU is the convergence of regions which will be provided by Structural Funds, Cohesion Fund and ISPA (Instrument for Structural Policies for Pre-Accession). For that purpose, some standards which must be met by project proposers, have been generated to evaluate the projects objectively. In that sense, CBA is required for the projects. In the work of Florio and Vignetti (2003), 240 projects ( $2 / 3$ of them are environmental and remaining is the transportation projects) have been analyzed by means of ISPA co-financing rates and determinants of CBA as financial rate of return (FRR) and economic rate of return (ERR or IRR). One of the foundations of the paper, which are crucial measures for project appraisal of EU commission, is that expected financial returns vary in a wide range before and after EU grant as well as the variability of co-financing rates amongst countries.

An example of CBA for tunnel construction is the work of Proost et al. (2005), in which constructing a new tunnel alternative to the existing one in Antwerp under Sheldt River in order to reduce congestion, is proposed. The expected cost of tunnel is more than $€ 1$ billion. For the analysis, three alternative tolling schemes comparing to do-nothing alternative have been conducted. With the $\% 5$ discount rate and 20 years time horizon it is concluded that the tunnel is worthwhile.

Another detailed study on tunnel construction is the publication of Anguera (2006). In his paper he conducted an expost analysis of Channel Tunnel, which links Britain to the Continent. He revealed that, ex-post financial analysis of the Tunnel for the $1987-2003$ period results with an IRR of -\%14.45 and a NPV of 5988 million $£$.

Another example of CBA for transportation projects is the work of Murty et al. (2006), which implements CBA for Delphi Metro Project consisting of two parts costing totally 144320 million Indian Rupees. Two kinds of approaches have been used for economic analysis. One of them assumes a suboptimal level of saving which leads social time preference rate to be lower than the rate of return on investment and a social premium on investment. The other one assumes optimal saving level and non-distorted capital markets. Therefore, rate of return on investment can be taken same as the social time preference rate. Regarding these approaches, IRR has been found as $\% 23,86$ and $\% 23,88$ respectively. And with discount rates $\% 8$ and \% 10, NPVs are 432387.5 and 232050.7 million Indian Rupees.
Although literature on CBA in Turkey is not wide enough there are a few examples for transport projects which should be mentioned here and also guided for the analysis part.

One of these studies is the publication of Cakır (1999), in which a comparison of Kınalı-Sakarya toll way and E-80 state road is made by using CBA including social and private costs and benefits. In that study, treasury bond annual interest rate of $\% 73.88$ had been used as a discount rate and NPV was found to be a positive value. IRR had been found as \% 78.71 and NPV had been calculated for different discount rates up to $\% 80$. Beyond that rate, NPV became negative. It had been concluded that toll way is economically more efficient than E-80 state road.

Another detailed study is the Ozkan's (2000) Ph.D. dissertation, in which classical cost benefit analysis and a Simple Multi Attribute Rating Technique (SMART) has been conducted. Here, only cost benefit analysis's results will be mentioned as they are related. In Ozkan's study, CBA is conducted for different highway projects that were ongoing by Republic of Turkey General Directorate of Highways (GDH). For all projects discount rate have been taken as $\% 12$. Then, projects have been ranked according to their benefit/cost ratios which are mentioned as follows. For the first case study in which AfyonSandıklı, Mekece- Adapazarı, Gazipasa- Alanya highway projects analyzed, $B / C$ ratios are $1.76,1.06$ and 0.51 respectively. For the second case study, in which Balıkesir-Susurluk- Karacabey, Bornova-Turgutlu-Salihli, Yalova- Topçular- Altınova and Samsun- Çorum highway projects analyzed, B/C ratios are found to be 2.2, 2.16, 1.38 and 1.36 respectively.

From the analyses mentioned above, the conspicuous point is the great difference between ERR and the discount rates used. While for EU the highest acceptable ERR is between \% 8 - $\% 10$, for Indian case $\% 22-23$ becomes acceptable. As well, for Turkey the rates are relatively high. In the logic of CBA, the differentiation of the rates amongst countries is an expected issue of fact; as the interest rates, inflation rates and other relevant determinants are various. As a general rule, higher rates are expected for developing countries due to volatility, inflation, higher interest rates, etc.

\subsection{Critiques and Limitations}

Although cost benefit analysis is the most widely used project evaluation method for over 40 years, it is also widely criticized. In this section, limitations and critiques will be discussed especially for the transportation project applications.

The main criticism or the weakness of the technique is the monetization of non-marketed costs and benefits and the externalities created by the project. This argument can also be stated in a more generalized way, named as the valuation problem. One side of this criticism states that although every- 
thing has a value they cannot and should not be monetized. In this aspect, value of life and time attract the attention of analysists. For valuing life there are two main approaches as human capital approach and willingness to pay approach. Henser et al. (2009) argued that willingness to pay approach is preferable to human capital approach and the latter is more suitable for the analysis of safety benefits of roads. The difficulty in valuing life is obvious but beyond its difficulty, the critique mentioned here states that there is no statistical life and human life cannot be measured. Also, the method of willingness to pay to avoid the risk of death is paradoxical and confused with the value of risk (Heinzerling and Ackerman, 2002). The other side of the criticism arises for the decision of whether to use the values before or after the project implementation. While the drawback of using the values after project implementation is the overestimation of the project effects, using the values before project would underestimate these effects (Panayatou, 2000).

Referring to monetization critique, measurement of accident cost savings and travel time savings, which depends on another controversial issue: valuing time, are the most problematic but also indispensable items of transportation projects. For the evaluation of accident cost saving, GDH uses a method which estimates years of productive life lost as the result of accident and adds the direct costs which includes medical care and other related legal services (Ozkan, 2000). Although this method seems useful and practical, besides the moral and ethical issues of valuing life, there are problems special to Turkey as the unavailability of direct cost data. Also, the underestimated causality and injury numbers is another problematic issue, as the victims are not followed after the accident whether they died or not.

Another problem is the measurement of travel time savings which is one of the most important benefits of transportation improvements. However, Lyons et al. (2006) argued that, the results of a questionnaire conducted to 26221 respondents in Britain revealed that there are variations in travel time use across different types of passengers and the perceived value of time also differs from passenger to passenger and from trip to trip. Similarly, Jiang and Morikawa (2004) concluded that, value of travel time savings is a function of marginal utility of travel time, marginal utility of leisure time, the case of travelling and individual perceptions. Although GDH provides a basis for calculation of passenger and driver time values for different kinds of vehicles, GDH itself does not include this item into the analysis but recommend that it should be included. The problem here, again for Turkey conditions, is the inconvenience of using average wage rate and unavailability of classification of trips due to purposes as leisure or business (Ozkan, 2000). Another mostly criticized issue of cost-benefit analysis is valuation of environmental effects. The application of CBA to environmental projects has a wide literature and far beyond the scope of this analysis. But the environmental issues, which are part of the transportation projects evaluation, arise as the external costs or benefits due to expected reduction of pollution,etc.. In broadest sense, environmental costs subject to transportation are; air pollution from emissions, global warming and ozone depletion. In most of CBA, environmental impacts are hard to be monetized thus, they are evaluated separately and concluded as complementary.

Another main criticism is the uncertainty problem which arises from the two sides of the analysis. First, benefit and cost streams for a given period in future are needed to be estimated. Secondly, the right discount rate should be chosen to convert these future streams into present values to make them comparable. Although benefit and cost streams are estimated by using some appropriate indicators, the valuation for unknown future conditions leads uncertainty and the analysis can be considered as suffering a great bias.

As a solution for the uncertainity problem, another evaluation technique, real options analysis, is offered. The real options theory, takes the uncertainties into account for the calculation of benefits and costs. In this approach, the probability of a change in demand conditions, macroeconomic fluctuations or the options to defer or postpone the investment etc. are also considered. Real option analysis is a decision tool which evaluates the probability that an infeasible investment will be feasible in the future. Unlike financial options, the underlying assets of real options are real and tangible.

The last important critique to be mentioned is that, the cost benefit analysis does not take into account the distributional effects. As the CBA serves within a partial equilibrium model, it is assumed that the overall surplus is distributed to whom benefits from it; but in general equilibrium process, these benefits are distributed to other economic agents (Quinet, 2006). Thus, the partial equilibrium assumption fails to consider the distributional effects, therefore a further analysis is needed to be made in general equilibrium framework.

\subsection{Bolu Mountain Tunnel}

Bolu Mountain Tunnel is located on the motorway which starts from Ankara, stretches up through Istanbul to Kapıkule Border Gate. The (Gerede-Ankara) Junction-IstanbulKapıkule Motorway is also designated as a road numbered as E-80. Bolu Mountain passage is in the mountainous area where severe winter conditions prevail, constitutes $25,5 \mathrm{~km}$ motorway and $1,6 \mathrm{~km}$ link road. The motorway has been designed as $2 \times 3$ lanes and link road has been designed as $2 \times 2$ lanes. The project consist of earthwork, tunnel, and some superstructure works. Bolu Mountain Passage starts from Kaynaslı, which locates at the 30th km of Gumusova-Gerede 
highway, passes Bolu mountain with a tunnel, and ends at the Yumrukaya. This road project includes 2871 meter long two tubbed tunnels, 4644 meter long four viaducts, 917 meter long three bridges, 76 meter crossover bridge and 682 meter long twelve underpass bridges. $(\mathrm{GDH}, 2007)$

After the earthquake in 1999 the tunnel was affected and damaged. This obliged to a change the itinerary of the project. The total length of the tunnel is about $2954 \mathrm{~m}$. The project is completed in 2007 and opened to the traffic.

Project had been financed by equity capital and external loans. The total estimated cost of the project is 686.267 .689 $\$$. But by the end of 2006 the actual costs reached to $\$ 952.001 .155$ (excluding Value Added Tax (VAT)) (GDH, 2007).

\section{METHODOLOGY}

In literature and practice, three decision rules; net present value, internal rate of return and benefit/cost ratio are widely used in project selection. The main point of the decision is the comparison of cost and benefit streams in a time dimension. The decision depends upon whether the benefits generated by the project exceed the costs.

\subsection{Net Present Value}

Net present value (NPV) is the most widely used method as a decision rule for project selection. NPV is the difference between the present values of benefits and costs. NPV can be calculated in two ways, either by taking the difference of separately discounted costs and benefits or discounting the net benefits (benefits-costs). For the chosen period, the project with the highest net present value can be selected as the most beneficial. If the analysis is done for a single project, the project is evaluated as worthwhile when the NPV is positive for the chosen discount rate. The most important issue here is the choice of the right discount or interest rate, which is commonly chosen as the social time preference rate. The general formula is given as below:

$$
N P V=\sum_{t=0}^{n} \frac{B_{t}-C_{t}}{(1+i)^{n}}
$$

Where $B_{t}$ is the benefits at time t; $C_{t}$ is the costs at time $\mathrm{t} ;{ }^{i}$ is the discount rate and $\mathrm{n}$ is the length of time for the project's benefit and cost streams.

\subsection{Benefit-Cost Ratios}

The benefit - cost ratio can be derived by two ways; one is to calculate present value of benefits over the present value of costs (including investment and annual operating costs) or the present value of net benefits over investment costs. The project should be selected if the $B / C$ is greater than 1 .

$$
B / C=\frac{\sum_{t=0}^{n} \frac{B_{t}}{(1+i)^{n}}}{\sum_{t=0}^{n} \frac{C_{t}}{(1+i)^{n}}}
$$

Yet another B/C measure can be stated as net benefit/ cost ratio which is the ratio of NPV over the present value of costs.

\subsection{Internal Rate of Return}

Internal rate of return (IRR) is the discount rate which equates NPV to zero. When this method is used, the project is chosen if the IRR exceeds the market interest rate or any other discount rate selected as a social discount rate. To calculate IRR, the following equation is solved for IRR.

$$
N P V=0=\sum_{t=0}^{n} \frac{B_{t}-C_{t}}{(1+I R R)^{n}}
$$

\section{DATA AND EMPIRICAL RESEARCH}

Bolu Mountain Tunnel has been constructed for about seventeen years and cost of the tunnel is relatively high considering the other highway projects implemented in Turkey. Bolu Mountain Passage is an important link between Istanbul and Ankara. The rationale for a tunnel construction is to provide safer transport conditions than the current passage of Bolu Mountain (D100 highway). Bolu Mountain passage had been one of the most dangerous parts of the Turkish Highways because of hard winter conditions. Heavy snow and dense fog during the winter time lessens the safety of the road. For these reasons a tunnel construction seemed to be an efficient way of improving the road safety and time saving. As the tunnel construction had not finished at the deadline planned by the earliest project appraisal, the necessity of tunnel construction became controversial among the society as it requires high investment costs which are withdrawn from other resources of the economy.

Although Bolu Mountain Tunnel had finished and opened to the use, the project itself is gripping to conduct a cost benefit analysis. The analysis is therefore an ex-post analysis as the project had been implemented. Thus, it investigates the future benefit streams expected to be generated and the internal rate of return has been used as the criteria to conclude if the project is worth to be implemented. As an alternative and a base-case, D100 Highway Bolu Mountain Passage part has been used. For the comparison and to check the consistency of the IRR result net present value has been calcu- 
lated for the discount rate of $\% 12$, which is the proposed rate by SPO (State Planning Organization) for infrastructure projects.

The computation of costs and benefits of the project are stated in the section below.

\subsubsection{Construction Costs}

Construction cost items consist of the earthwork, superstructure, major and minor artworks. Project preparation costs are also counted as construction costs. The data has been derived from the GDH Progress Certificate of January 2006. Cost data includes the payments made to the contracting firm during the project preparation period starting from the contract date of 1987 to January 2006 amounting to $\$ 2.753 .974$ (excluding VAT) and project implementation (construction) costs starting from 1990 amounting to $\$ 949.274 .181$ (excluding VAT) by 2007. The data is used in the analysis after subtracting the VAT payments since the tax items are excluded in benefit and cost analyses. Then for consistency, dollar values of cost items are converted to Turkish Lira (TRY) by using the annual exchange rate values gathered from Central Bank of Turkish Republic.

\subsubsection{Maintenance Costs}

Within the lifetime of a highway, some repairments (patches, drain cleaning, reshaping of slopes etc.) and maintenance services should be implemented in order to keep the quality of the highway at the desired level. Maintenance cost consist of three parts; routine maintenance, periodical maintenance, and extraordinary maintenance. Routine maintenance is the maintenance of roads provided annually while the periodical maintenance is conducted at some years defined by GDH that differs by the type of the road. Extraordinary maintenance appears in the cases of snow fighting, flood and landslides.

These cost items are assumed to be constant over years. Since the data gathered from GDH is the maintenance cost for one kilometer of highway, the calculation process of this cost item includes multiplication of the length of the project road $(27.2 \mathrm{~km})$ with the maintenance cost per kilometer. For the Bolu Mountain Tunnel, the average maintenance cost per one km is 120458 TRY including toll collection costs. (GDHa,2010).

As the maintenance costs gathered from GDH includes toll collection costs for the newly constructed Anadolu Otoyolu (Anatolian Highway), which the Bolu Mountain Tunnel is one of its sections, revenues received from toll payments are included in the analyses as a cost reducing item. Toll charges for motorways differ according to the length of the trip and the type of the vehicle used. Since estimating the future destinations of the vehicles using the motorway is difficult, we assigned a rough toll charge estimate for every type of vehicle. We assigned 15 TRY for automobiles, vans, pick-ups etc; 25 TRY for buses and trucks and 34 TRY for trailers.(GDH, 2010) The assigned toll charges for different types of vehicles are multiplied by Annual Average Daily Traffic (AADT) figures to get the total estimated toll revenues. The actual AADT figures for the D100 highway and Bolu Mountain Tunnel is given in Table 1 and Table 2 respectively. GDH, declares the AADT figures for motorways in only two classes: light and heavy classes. In order to compare two roads and make precise calculations we estimated the AADT figures for the other classes by using their percentages in the AADT of D100 highway by the relevant year. Automobiles and light commercial vehicles are classified as light; whereas buses, trucks and trailers are classified as heavy duty vehicles. The distributed AADT figures for Bolu Mountain Tunnel are given in Table 3.

Table 1: AADT Figures for D 100 Highway

\begin{tabular}{|l|r|r|r|r|r|r|}
\hline Years & Automobile & $\begin{array}{c}\text { Light } \\
\text { Commercial } \\
\text { Vehicle }\end{array}$ & Bus & Truck & Trailer & Total \\
\hline $\mathbf{2 0 0 5}$ & 13979 & 1268 & 1691 & 4416 & 2043 & 23397 \\
\hline $\mathbf{2 0 0 6}$ & 13894 & 734 & 1343 & 4167 & 3092 & 23230 \\
\hline $\mathbf{2 0 0 7}$ & 5882 & 672 & 522 & 2064 & 1824 & 10964 \\
\hline $\mathbf{2 0 0 8}$ & 4016 & 307 & 312 & 1565 & 1359 & 7559 \\
\hline $\mathbf{2 0 0 9}$ & 4218 & 301 & 386 & 1441 & 1316 & 7662 \\
\hline
\end{tabular}

Table 2: AADT Figures Bolu Mountain Tunnel

\begin{tabular}{|r|r|r|r|}
\hline \multicolumn{1}{|c|}{ Years } & \multicolumn{1}{c|}{ Light } & \multicolumn{1}{c|}{ Heavy } & \multicolumn{1}{c|}{ Total } \\
\hline $\mathbf{2 0 0 7}$ & 11136 & 7509 & 18645 \\
\hline $\mathbf{2 0 0 8}$ & 10641 & 7464 & 18105 \\
\hline $\mathbf{2 0 0 9}$ & 11463 & 7373 & 18836 \\
\hline
\end{tabular}

Table 3: Distributed AADT Figures for Bolu Mountain Tunnel

\begin{tabular}{|l|r|r|r|r|r|r|}
\hline Years & Automobile & $\begin{array}{c}\text { Light } \\
\text { Commercial } \\
\text { Vehicle }\end{array}$ & Bus & Truck & Trailer & Total \\
\hline 2007 & 9994 & 1142 & 889 & 3514 & 3106 & 18645 \\
\hline 2008 & 9885 & 756 & 720 & 3610 & 3135 & 18105 \\
\hline 2009 & 10699 & 764 & 905 & 3380 & 3087 & 18836 \\
\hline
\end{tabular}

Source: GDH Traffic Volume Maps (GDHb, 2005, 2006, 2007, 2008, 2009, 2010)

Also to estimate the AADT for future years, we assumed that AADT will increase at a rate of $\% 6$ each year. Since the expected increase in AADT exceeds the expected increase in maintenance costs, after 2046 toll collection revenues exceed the maintenance costs, thus generate a net benefit. 


\subsubsection{Accident Cost Savings}

One of the most important benefits of highway improvement is the expected reduction in the number of accidents. In the Bolu Mountain Passage case, this expectation plays a more important role since this part of the road has suffered from high number of accidents until the tunnel started to operate. The main causes of the accidents were the bad weather conditions especially in winter, the structure of the mountain road which has lots of hairpin bends and the congested traffic as a result of being the main stream road between Ankara (the capital of Turkey) and Istanbul (the largest city in Turkey).

Accident cost saving valuation is crucial because it is hard to express the costs of personal injuries or death in monetary terms as we have discussed previously. According to an approach in the literature relating to the evaluation of accident costs, a monetary value cannot and also should not be attached for a human's life. But in this analysis, the evaluation of personal injuries and death is included in the accident cost savings item in monetary terms. To express these items in monetary terms the "loss of production" approach is used.

To calculate the loss of production, minimum wage is taken as the base rate. In case of fatalities, the loss of production is accepted as 35 years. In case of injuries, it is assumed that of all injured people, $\% 40$ for 1 month, $\% 30$ for 3 months, $\% 20$ for 6 months and the rest during 35 years will not be able to participate in labor force. (Ozkan, 2000).

In Turkey, accident direct cost information is unavailable therefore this item is excluded in some analysis while computing accident costs. Also accident victims are not followed after the accident, therefore accident cost values of Turkey are very low compared to developed countries because of the underestimation of accident costs.

Also the material damage costs are calculated and included in the analysis. The average material damage cost per accident is found to be 2088 TRY. (GDH, 2008) Multiplying this figure with the estimated reduction in the number of accidents results as the yearly accident cost savings.

As the accident cost saving is a benefit in the form of cost reduction, the values are calculated for the D100 highway with the assumption of the new constructed tunnel will decrease number of accidents by $\% 60$. The accident numbers have been derived from the Bolu Police Department.

\subsubsection{Vehicle Operating Costs}

Vehicle operating costs (VOC) are the costs which are borne by the road users for vehicle operating and depreciation. This cost item is of crucial importance for the evaluation of road projects along with construction and maintenance costs. Vehicle operating cost savings occur due to expected reductions in roughness of pavements as a result of pavement improvements.

The first stage of VOC savings calculation involves the forecasting of AADT over years. The annual growth rate of the traffic has been estimated at $\% 6$.

The vehicle operating costs of different types of surface conditions is published yearly by the Ministry of Public Works and Settlement for each kind of vehicle. Vehicle operating cost for each road (Bolu Tunnel and D100 highway) is calculated by multiplying the length of the road with AADT figures and the given VOC figures per vehicle. Then the total saving in vehicle operating cost is computed by taking the difference of the values of old and new roads. The VOC figures of GDH for the asphalt concrete roads are given in Table 2. The terrain type of D 100 Highway is "Mountain" whereas the terrain type of tunnel is flat.

Table 4: Vehicle Operating Costs

\begin{tabular}{|c|c|c|c|c|c|}
\hline $\begin{array}{l}\text { TYPE OF } \\
\text { PAVEMENT }\end{array}$ & $\begin{array}{c}\text { TERRAIN } \\
\text { TYPE }\end{array}$ & AUTOMOBILE & BUS & TRUCK & TRAILER \\
\hline $\begin{array}{l}\text { Asphalt } \\
\text { Concrete }\end{array}$ & $\begin{array}{l}\text { FLAT } \\
\text { MOUNTAIN }\end{array}$ & $\begin{array}{l}0.1948 \\
0.1935\end{array}$ & $\begin{array}{l}1.2565 \\
1.6171\end{array}$ & \begin{tabular}{|l|}
0.8756 \\
1.3547
\end{tabular} & $\begin{array}{l}1.5181 \\
2.2792\end{array}$ \\
\hline
\end{tabular}

Source: $\mathrm{GDH}^{\mathrm{C}}$, Division of Strategic Planning (2007)

\subsubsection{Travel Time Savings}

Another important benefit of a highway improvement is the expected savings generated in travel time due to improved road conditions. The net figure of travel time savings is a function of traveler's income, type of trip, day of the week etc... The estimation of value of travel time has some shortcomings. First of all, the value of travel time depends on trip purpose. For example, the value of a business trip is equal to the employee's wage rate. Second, the value of travel time varies from person to person according to their income level. But, according to this approach, travel time savings calculation of unemployed or people who are not in the labor force (retirees, housewives etc...) is problematic. Since deriving the income and other necessary data accurately for the users of the road to calculate travel time savings is practically impossible, some estimations are made in order to give a rough idea of travel time savings. The estimation is based on the value of time figures calculated by GDH for different types of vehicles as passenger and driver time values. The calculations of value of time by GDH are given in the table below:

It is assumed that the new road will shorten the traveldistance time by 2.5 hours on the average, thus travel time 
savings have been accounted by multiplying the time values by the number of vehicles passing on the new road.

The values are used in the analysis as a cost reducing item of vehicle operating cost. The values can also be stated as a decrease in opportunity cost of using the new road by the reduction in time.

After calculating all benefit and cost items separately net benefit stream (benefits-cost) has been calculated and this stream has been deflated by using the deflator figures for the transportation projects published by SPO. The deflator series were created as $2008=1$; so the net benefit stream between 1987 and 2008 are deflated with the series but deflators through 2010 to 2056 are kept constant at 2010 deflator figure, since the all the monetary costs are kept constant at 2010 prices.

Table 5: Value of Time

\begin{tabular}{|c|c|}
\hline 1-PASSENGER TIME & \\
\hline Income per capita (2009) : & 13.269 TRY/year \\
\hline & $1105.75 \quad$ TRY/month \\
\hline Assuming the monthly working he & 176 hours; \\
\hline wage per hour: & 1015.75/176=6.28 TRY/hour \\
\hline Passenger Time Value : & 6.28 TRY/hour \\
\hline 2- DRIVER TIME & \\
\hline BUS & \\
\hline 2 Drivers : $(2 * 1250)$ & $2.500 \mathrm{TRY} / \mathrm{month}$ \\
\hline 1 co-driver : $(1 * 600)$ & 600 TRY/month \\
\hline monthly wage : & 3100 TRY/month \\
\hline Wage per hour: & $3.100 / 176=17,614 \mathrm{TRY} /$ hour \\
\hline Driver time value for bus : & $17,614 \mathrm{TRY} /$ hour \\
\hline TRUCK, TRAILER & \\
\hline 2 Drivers : $(2 * 1250)$ & $2.500 \mathrm{TRY} / \mathrm{month}$ \\
\hline wage per hour: & $2.500 / 176=14,205$ TRY/hour \\
\hline Driver time value for truck and & $14,205 \mathrm{TRY} /$ hour \\
\hline 3- PASSENGER PER VEHICLE & \\
\hline Car & 2.5 \\
\hline Bus & 28.3 \\
\hline
\end{tabular}

Source: $\mathrm{GDH}^{\mathrm{C}}$, Division of Strategic Planning (2007)

In the earlier versions of this paper in 2007, the IRR and NPV figures were calculated by assuming $\% 80$ of the D-100 highway traffic will be diverted to the Tunnel since the actual traffic figures were not observed yet. The result of the analysis for a 50 year period with a $\% 12$ discount rate was as below:
Table 6: Results of 2007 Calculations Based on Assumptions

\begin{tabular}{|l|r|}
\hline NPV & -218.481 .574 TRY \\
\hline IRR & $\% 9,11$ \\
\hline B/C & 0,51 \\
\hline
\end{tabular}

When we reevaluated the project by using latest cost and actual traffic figures, the results were almost the same as the previous calculations which are given below:

Table 7: Results of 2010 Calculations Based on Actual AADT Figures

\begin{tabular}{|l|r|}
\hline NPV & -325.012 .112 TRY \\
\hline IRR & $\% 6,73$ \\
\hline B/C & 0,29 \\
\hline
\end{tabular}

The calculations show that if the percentage increase in AADT exceeds \%14 per year, the project becomes feasible; also even if the tunnel decreases number of traffic accidents by $\% 100$ the NPV of the project is still negative.

As we have discussed before, another project evaluation method, which avoids some shortcomings of the NPV methodology is real options analysis. In this analysis, the option to expand, delay or the option to wait is also evaluated. This analysis may overcome the static nature of NPV technique. For example, a project with a negative NPV may still be feasible under real options if the future demand conditions are optimistic.

The valuation of real options is somewhat similar to financial options; the price of the underlying asset is the NPV of the project, the strike price is the cost of the project, risk free rate is the discount rate etc... But since the NPV of our case is negative in almost all logical cases, traditional option valuation techniques like Black -Scholes or Binomial models are useless.

In Bolu Mountain Tunnel case, we could not conduct a real option analysis since the tunnel is already constructed. Real options analysis is not a suitable technique for ex-post cases. But as an option, the government could have waited until the end of the project preparation period (1987 - 1994) without starting to implement it in 1990. In 1994 depending on the new demand conditions the project may have been cancelled out. Since we don't have the 1994 data we couldn't run the analysis but for today the NPV of the project preparation costs were nearly 25 million TRY which is far less than 325 million. That is, if the government were to cancel out the project in 1994 without starting to implement it, the society would be better off. 


\section{CONCLUSIONS}

Bolu Mountain Tunnel which is evaluated in this paper has been constructed in seventeen years and cost of the tunnel is relatively high considering the other highway projects implemented in Turkey. Bolu Mountain Passage is an important link between Istanbul and Ankara. The rationale for a tunnel construction is to provide safer transport conditions than the current passage of Bolu Mountain (D100 highway).

According to the results, at first sight it seems that Bolu Mountain Tunnel is not economically feasible since the NPV of the costs of the project, exceeds the NPV of the benefits. And the IRR of $\% 6.70$ is lower than the $\% 12$ discount rate. By theory IRR which is lower than the discount rate means that the project is not worth while.

The main reason for the negative value of NPV is the high construction costs amounting to almost $\$ 1$ billion. The estimated costs of the project was $\$ 686$ millions but the unplanned cost items caused the unfavorable variance in the construction costs. The cost increasing items were not only related to the tunnel. For example, the construction costs of four viaducts also share the equal responsibility with the tunnel for increasing the costs. The risks appeared after the two earthquakes in 1999 (Marmara and Duzce), caused the estimated costs of the viaducts to increase.

Also the unplanned delays of the project caused the costs to increase. Unplanned times extensions (six times), two major earthquakes, two floods and above all the lack of appropriation caused the delays. As a result of the delays, the actual prices of the construction items exceeded their projected prices.

While evaluating the negative value of the NPV, one should take into account that, the analysis has been conducted under certain assumptions like \% 12 discount rate, 50 years economic life etc. It is obvious that, under different assumptions, different results would occur. Also it should be stated that, the salvage value of the tunnel is not calculated for the CBA analysis. Besides, the environmental benefits of the project are not included.

Finally, before concluding that the Bolu Mountain Tunnel is not economically feasible, it should be kept in mind that in these kinds of CBA analyses, the measurement of the externalities created by the project and the monetization of costs and benefits especially of those which are non-marketed are problematic. In this aspect, accident cost saving valuation is crucial because it is hard to express the costs of personal injuries or death in monetary terms. Although the calculations state that, the construction of the tunnel is economically not feasible, it is a fact that the tunnel has improved the road safety. It is obvious that safer transport conditions will lead to fewer traffic victims and the value of human life is beyond any reckoning.

\section{END NOTES}

1. This paper is a revised and updated version of the first author's master dissertation at Izmir University of Economics with the supervision of Prof. Dr. İsmail Bulmuş. We are grateful to Prof. Dr. İsmail
Bulmuş for his comments and suggestions on the earlier versions of this paper. Needless to say, the errors and omissions are solely the authors' responsibility.

\section{REFERENCES}

Adler, A. H.(1975) Ulaştirma Projelerinin Ekonomik Değerlendirilmesi Örnek Etüdleri. Translated by Cahit Yalgın. General Directorate of Highways Publications, Ankara.

Anguera, R. (2006) The Channel Tunnel--an ex post economic evaluation. Transportation Research Part A: Policy and Practice, Volume 40, Issue 4, 291-315.

Boadway, R. (2006) Principles of cost-benefit analysis. Public Policy Review. Vol.2, No.1.

Cakır, T. (1999) Türkiye’de Kamu Ekonomisince Üretilen Karayolları Hizmetlerinde Fayda-Maliyet Analizi Tekniğinin Uygulanabilirliği. Anadolu Üniversitesi Yayınları, Eskişehir.

Adler, M. D. and Posner, A., E. (1999) Rethinking cost-benefit analysis. The Yale Law Journal. No. 109.

Ellerman, D. (2004) On a difficulty in welfare economics: numeraire illusion in the Marshall-Pigou-Kaldor-Hicks methodology. University of California at Riverside Working Paper.

Florio, M. and Vignetti, S. (2003) Cost-Benefit Analysis of Infrastructure Projects in an Enlarged European Union: An Incentive-Oriented Approach.

Fosgerau, M. and Pilegaard, N. (2007) Cost-Benefit Rules for Transport Projects When Labor Supply is Endogenous and Taxes are Distortionary. MPRA.

GDH $^{\mathrm{a}}$, (2009) 2009Yılı Otoyollar Bakim-Işletme ve Ücret Toplama Maliyetleri, Ulaşım ve Maliyet Etüdleri Şubesi Müdürlüğü, http:// www.kgm.gov.tr/SiteCollectionDocuments/KGMdocuments/Istatistikler/YapimBakimIsletmeMaliyet/2008\%20Y11 $\% 20$ Otoyollar\%20 Bakım\%20-\%20İşletme\%20ve\%20Ücret\%20Toplama\%20Maliyetleri\%20.pdf,08.07.2010 
GDH (2010), http://www.kgm.gov.tr/SiteCollectionDocuments/KGMdocuments/Istatistikler/YapimBakimIsletmeMaliyet/otoyolmaliyet2009.pdf, 15.07.2010

GDH (2008), http://www.kgm.gov.tr/kaza2k.doc, 21.07.2008

$\mathrm{GDH}^{\mathrm{b}}$, ( 2010) 2009 Trafik ve Ulaşim Bilgileri: Otoyollar ve Devlet Yollarinin Trafik Dilimlerine Göre Yillik Ortalama Günlük Trafik Değerleri ve Ulaşim Bilgileri, Strateji Geliştirme Daire Başkanliği Ulaşim ve Maliyet Etütleri Şubesi Müdürlüğü, http://www.kgm.gov. tr/SiteCollectionDocuments/KGMdocuments/Istatistikler/Trafikve UlasimBilgileri/09TrafikUlasimBilgileri.pdf 15.07.2010 http:/www. kgm.gov.tr/Sayfalar/KGM/SiteTr/Istatistikler/TrafikUlasimBilgileri. aspx, 15.07.2010

$\mathrm{GDH}^{c}$, Karayolları Genel Müdürlüğü Stratejik Planlama Şubesi Müdürlügü̈.(2007) Karayolu Planlaması Bilgileri El Kitabı. (GDH, Department of Strategic Planning: Handbook for Motorway Planning).

GDH, Karayolları Genel Müdürlüğü. (2006) Anadolu Otoyolu Gümüşova-Gerede Kesimi İnşaat Kontrolu Mühendislik Hizmetleri İş İlerleme Raporu, Yüksel Proje.

Heinzerling, L. and Ackerman, F. (2002) Pricing the priceless: Cost-Benefit analysis of environmental protection. Georgetown Environmental Law and Policy Institute.

Hensher, D. A., Rose, J. M., Ortuzar, J. and Rizzi, L. I. Estimating the willingness to pay and value of risk reduction for car occupants in the road environment. Transportation Research Part A: Policy and Practice, In Press, Corrected Proof (www.sciencedirect.com/science/article/B6VG7-4WP4BF4-1/2/f0c5f0a1b3d2c7b9b5204e1bcd16d2f5).

Jiang, M., Morikawa, T. (2004) Theoretical analysis on the variation of value of travel time savings, Transportation Research Part A: Policy and Practice, Volume 38, Issue 8, 551-571.

Kula, E. (2006) The social discount rate in cost-benefit analysis: the British experience and lessons to be learned. Milan European Economy Workshops Working Paper.

Lundholm, M. (2005) Cost - Benefit analysis and the marginal cost of public funds. Department of Economics, Stockholm University.

Lyons, G., Jain, J. and Holley, D. (2007) The use of travel time by rail passengers in Great Britain, Transportation Research Part A: Policy and Practice, Volume 41, Issue 1, 107-120

Mishan, E.J.(1975) Cost-Benefit Analysis; An Informal Introduction, $2^{\text {nd }}$ edit, Gresham Press, London.
Murty, M.N., Dhavala, K. K, Ghosh, M. and Singh, R.(October,2006) Social cost-benefit analysis of Delphi Metro. MPRA, No.1658

Nas, T. (1996) Cost Benefit Analysis Theory and Application. Sage Publications, California. p. 57

Nijkamp, P., Ubbels B. and Verhoef, E. (2002) Transport investment appraisal and the environment. Tinbergen Institute Dsicussion Paper.

OIM, Benefit Cost Analysis for Transportation Projects, Mn/DOT Benefit Cost Analysis Guidance (June 2005) (http://www.oim.dot.state. mn.us/EASS/, 20/07/2008).

Ozkan, N. (2000) Refinement of benefit cost analysis results for highway projects. Ph.D Thesis, METU Department of Civil Engineering. p: $18,63,75,76$.

Panayotou, T. (September,2000) Basic concepts and common valuation errors in cost-benefit analysis. International Development Research Centre. Ottowa. p: 10.

Proost, S., Van der Loo, S., De Palma A. and Lindsey, R., (2005) A Cost-Benefit Analysis of tunnel investment and tolling alternatives in Antwerp. Katholieke University Of Leuven Center For Economic Studies Working Papers.

Quinet, E. (2006) Transport cost benefit analysis in France: Recent changes, progress and shortcomings. Milan European Economy Workshops Working Paper. p:13.

Sugden, R. and Williams, A. (1978) The Principles of Practical CostBenefit Analysis. Oxford University Press, Britain.

Unsal, H. (2004) Kamu hizmetlerinin planlanmasinda fayda-maliyet analizi ve uygulanabilirliği, (Cost benefit analysis of public services planning and its applicability). Gazi University Social Sciences Institute Journal, No:1.p:1.

Watkins, T. An introduction to cost benefit analysis. San José State University Department of Economics, Silicon Valley \& Tornado Alley USA.

Weber, A. T. (2003) An exact relation between willingness to pay and willingness to accept. Economics Letters.

Weisbrod, E.G. and Beckwith J. (1992) Measuring economic development benefits for highway decision-making: The Wisconsin Case. Transportation Quarterly, Vol.46., No.1.

Zerbe, O. R. Ethical benefit-cost analysis. The Evans School of Public Affairs and The Law School, The University of Washington. 